Canadian Journal of Family and Youth, 13(2), 2021, pp. 95-121

ISSN 1718-9748@ C University of Alberta

http://ejournals,library,ualberta.ca/index/php/cjfy

\title{
Frost, Hail, Prairie Fire and Weeds: \\ Families Harvesting Crops on a Saskatchewan Homestead, 1872-1914
}

\author{
Sandra Rollings-Magnusson
}

\begin{abstract}
Under the Dominion Lands Act of 1872, certain regulations needed to be met by homesteaders to ensure that they could eventually acquire title to their 160 acres of free land. This land needed to be cleared, seeded and harvested, however problems existed which threatened the successful cultivation of a homesteader's crops. Early frosts, hail, prairie fires and weeds would destroy the plants as would pests such as grasshoppers, cutworms, and gophers. Trying to combat mosquitoes, and bulldog flies while working the fields also posed a hazard to both the homesteader and their working farm animals. Using survey data collected by the Provincial Archives of Saskatchewan in the mid-1950s, this paper highlights the labour-intensive nature of farm work and the numerous difficulties faced by homesteaders and their families in their attempt to successfully produce crops.
\end{abstract}

Keywords: Canada, homestead, wheat, harvest, work, prairies

\footnotetext{
Sandra Rollings-Magnusson is an Associate Professor of Sociology at MacEwan University in Edmonton, Alberta. For over thirty years, she has researched the settlement process/homesteading era on the western Canadian prairies that occurred between 1867-1914. She has written numerous journal articles on the topic as well as two books ("Heavy Burdens on Small Shoulders" published by the University of Alberta Press and "The Homesteaders" published by the University of Regina Press.)
} 


\section{Introduction}

According to the stipulations set out in a Canadian Federal Government Order-inCouncil dated March, 1871, settlers had to follow homestead regulations if they wished to obtain title to their land. Not only would the settler applying for the homestead land have to pay a $\$ 10$ registration fee, but he also had to be male, or head of household, and 21 years of age or over. The registrant was also expected to take physical possession of his registered land within six months after applying and was required to live on the land for at least six months of every year for five years. One month later, a revision was made to the Order in that the residency requirements were lessened to three years. In 1872, the Dominion Lands Act ${ }^{1}$ was created which replaced the two Orders-in-Council. This new Act specified that the age limit for registering was lowered to eighteen years of age. In 1884, requirements became more restrictive with an amendment to the statute which indicated that homesteaders were required to break at least forty acres and have twenty-five acres cropped by the end of the three-year period. This was subsequently reduced to fifteen acres broken with ten cropped within two years in an 1886 amendment. ${ }^{2}$ In 1891, further revisions were made to the Act with homesteaders being required to break forty acres and crop twenty-five acres within three years. ${ }^{3}$ By 1908 , further changes were implemented in that homesteaders were expected to crop twenty acres and break a total of thirty acres. ${ }^{4}$ If homesteaders did not meet the federal government requirements regarding productivity within the specified time frame, homesteaders faced the possibility of their registrations being cancelled and losing their land. ${ }^{5}$

In order to ensure that they would gain title, homesteaders and their families placed a high priority on developing their land. Even though a gendered division of labour existed at that time with men being primarily responsible for field work and women undertaking all domestically-related chores, all members of the family, including children as young as four years old were expected to help when called upon. When their assistance was needed in the wheat fields, particularly during the periods of seeding and harvesting, all able-bodied family members became engaged in the process. The men would be working with oxen or horses to remove trees and plough the centuries-hardened acres of sod, while women and children would help to clear the land of stones and weeds. Once the land was free of obstructions, the seeding process began with many families walking and spreading the seed by hand. Over time, this process became more mechanized and efficient with wheeled broadcasters being used to crop the land. Similarly, during the threshing season, men and women would cut down the crops with a scythe or sickle, and bundle the stalks into stooks. Once the stooks were dry, they were piled into a wagon and taken to the barn, where all family members would thresh the kernels from the stalks. Flailing the wheat and winnowing were then undertaken, with the grain being collected and taken to market. ${ }^{6}$

Whether homesteaders were clearing land or cultivating crops, it is evident that many hands were needed given the workload associated with crop production. Homesteaders, who had prior knowledge of farming and animal husbandry had an advantage over others who were unfamiliar with the process. While many settlers who came to western Canada had previously been farmers or had worked as labourers on farming operations, there were some people who registered for homestead land that did not have any kind of agricultural experience. In these cases, life on a Saskatchewan ${ }^{7}$ homestead would have been particularly challenging. 
Whether they had farming experience or not, some settlers, particularly those emigrating from western and eastern Europe to Saskatchewan, were unaware of some of the more unique difficulties they would be encountering when trying to grow their crops on the Canadian prairies. Early frosts, hail, and prairie fires could quickly destroy the family's crops as could local pests such as gophers, cutworms, and grasshoppers. Fighting mosquitoes and bulldog flies while trying to work the fields also posed a threat to homesteaders and their farm animals. These biting insects would wreak havoc on those they attacked, with farm animals going out of control and homesteaders fighting to keep the pests at bay with smudges.

Dealing with these problems made life very difficult for homesteaders and their families. In addition, the lack of advanced farm machinery and technology offered little respite to those early homesteaders who had to manually work their land. This paper highlights the labour-intensive nature of field work and the numerous problems faced by homesteaders in their attempt to successfully harvest crops. Recognizing the struggles and strain experienced by those who settled on the Canadian prairies not only provides a clearer picture of homesteading life, but also gives insight into the amount of determination and hard work needed to persevere over all of the obstacles faced by settlers in their quest to gain title to their land.

\section{Method}

In the mid-1950s, the Provincial Archives of Saskatchewan (previously known as the Saskatchewan Archives Board) undertook a major research project, the purpose of which was to shed light on various aspects of pioneer life in Saskatchewan between 1876 and 1914. In order to obtain as much information as possible, the Board created and distributed ten different questionnaires to various individuals across the province who had lived and experienced the province's early years. Each questionnaire related to some particular aspect of prairie social life such as general farming experiences, government, religion, housing, health, education, recreation, folklore, and diet. The questionnaires were sent to a variety of locations such as nursing homes, social clubs, and church groups and were completed on a voluntary basis. Depending on their own personal preferences and ability to remember specifics on particular topics during the pioneer era, respondents were free to answer any questionnaire that appealed to them. ${ }^{8}$

The survey which focused on new settlers developing a homestead and growing and harvesting crops was formally entitled Pioneer Farming Experiences, Saskatchewan Archives Questionnaire \#6 and was completed by 206 individuals $^{9}$ (29 women and 177 men). There were over 110 questions included, most of which were open-ended. Given this format, respondents had the opportunity to comment or provide fuller details on their daily life and work routines.

The first part of the questionnaire dealt with introductory queries such as when and where respondents settled in Saskatchewan and their previous experience with farming. The second part included details as to how much land was broken and cropped by the respondents 
during their first few years of homesteading. Questions pertaining to animal management, in particular, how the respondents handled the oxen and/or horses that were used for working in the fields, were also set out in this section.

In the third part of the questionnaire, respondents were questioned about the individual labour contributions of their family members, and the hazards or difficulties that they encountered while living and developing their homesteads. Not only were respondents asked to comment on problems relating to hail and frost, weed invasions and prairie fires, but they were also asked to detail the problems associated with grasshopper, cutworm, fly and mosquito infestations, In the latter part of the questionnaire, respondents were asked to provide accounts of any interesting experiences that they had with early farming practices in the province.

In order to undertake a thorough analysis of this data, information provided by the respondents was numerically coded and entered into a statistical software program. Once completed, the findings were examined and all relevant patterns and trends relating to the personal characteristics of the pioneers and their farming experiences of breaking and cropping and finally harvesting their crops were identified. The results are set out below.

\section{Background Characteristics of the Respondents}

The majority of respondents (95 or $51.1 \%$ ) reported that they migrated or immigrated to Saskatchewan between the years of 1899 and 1906 while the second largest number of people (61 or 32.8\%) moved to the province between 1907 and 1914. Fewer numbers travelled to the area in the earlier years with only seventeen respondents $(9.1 \%)$ arriving between 1883 and 1890 and thirteen $(7.0 \%)$ arriving between 1891 and $1898 .^{10}$

In terms of where these respondents decided to settle, results indicated that they chose homestead locations that were widely scattered across the province. For example, five respondents stated that they had established themselves in the Saskatoon area, four settled in Star City, and three each resided in Battleford and Swathmore. Two responses were given for each of Adanac, Annaheim, Cressman, Lanigan, Longworth, Maple Creek, Nokomis, Prince Albert, Spalding, Regina, and Wadena, while a number of single responses were given for such places as Balgonie, Fort Qu'Appelle, Gull Lake, Kenaston, Lemsford, Melfort, Whitewood, Nutana, and Oxbow.

Respondents were also queried as to why they chose a particular area in which to settle. In the majority of cases, 45 respondents $(25.6 \%)$ indicated that they were looking for good farmland and an opportunity to homestead. Mrs. C.E. Diggle ${ }^{11}$, for example, reported that her father "came from Winnipeg with $\$ 5,000$ worth of furs in Red River carts, wintered at Touchwood Hills and drove to Prince Albert in the spring. [He] liked the river, the soil, the woods and lakes; married and settled there on a farm in 1876." Richmond Bayles ${ }^{12}$ also recounted the story of his father who moved his family from England in 1893. His father had heard that Canada "was a good country for a man and his family of three to start life afresh". Likewise, Herbert Anslow's father ${ }^{13}$ decided that he, his wife and children should also emigrate to Canada from England as he believed that there were great opportunities available for everyone in the new country. 
Thirty-one respondents $(17.6 \%)$ stated that they had been influenced by other people such as friends and acquaintances, who were travelling to the province. Joseph Wilson ${ }^{14}$ indicated that he and his friends agreed to register for ten homesteads together so that they would be close to each other and be able to help each other out when proving up their land. One other respondent, Albert Elderton ${ }^{15}$ stated that while working on a small steamboat on Last Mountain Lake ${ }^{16}$ in 1909, he had overhead passengers talking about the homesteads that they were planning to acquire. He found their excitement contagious and as a result, he indicated that he got "land fever, got time off from the boat and went to Moose Jaw and filed blind" on a piece of land.

Twenty-one others (11.9\%) reported that they were compelled to move to a particular locale in the province as they had relatives who had previously settled there. John Dickey ${ }^{17}$, for example, stated that his "brother-in-law's brother lived there" and that "he told me anything I wanted to know about it." Eventually, the brother-in-law convinced John to come out west to work for him on his farm. Mary Brownridge ${ }^{18}$ and her family were also encouraged to move to Saskatchewan by a relative. Her husband's brother had previously moved to the province and homesteaded in 1882, however he wished to leave his homestead for a period of time as he wanted to get married in Ontario. He convinced Mary and her family to visit his homestead and look after his interests while he was gone. However, as Mary indicated, her family took up the homesteading requirements for themselves as her brother never returned from his marriage trip.

Twelve respondents $(6.8 \%)$ stated that they had been influenced by the advertisements in newspapers and government pamphlets or by land agents. ${ }^{19}$ Martin Duesterbeck ${ }^{20}$, for example, indicated that he had been reading a newspaper entitled "The North Western" which included a story about four families who had successfully migrated and homesteaded in the Edenwold district of Saskatchewan. Frank Baines ${ }^{21}$ reiterated his story of a land agent in Toronto by the name of John T. Moore. This man "gave a glowing account of the country. 160 acres of good land to be secured for only \$10.00!" Frank and his family "fell under the spell binding oratory" of this land agent and as a result travelled west to obtain a homestead. Like the Baine's family, Edith Stilborne's family ${ }^{22}$ was also captivated by salesmanship as she stated that their spirit for adventure was incited by an agent of [a] Colonization Company who came to England to induce settlers to emigrate and settle in the prairie province." This agent gave her parents a "glorified description of the possibilities of the land and its productiveness" and told them that they could make their fortune in just five years after which they could return to England and live in luxury. After being swayed by the agent's account, Edith reported that she and her father and mother travelled to the prairies to homestead even though her father had no experience with farming. As she stated, "he learned the hard way, by trying and failing, but not being daunted, trying again." 23

In order to gain a fuller understanding of how well individuals and their families would be able to cope in a homesteading situation, respondents were also asked about their previous farming experience. Out of the 178 respondents who answered this question, ninety-nine (or $55.6 \%$ ) indicated that they were fully versed in farm practices as they had been born and raised on a farm. John Peacock ${ }^{24}$, for example, indicated that his family had previously owned a "farm in the bush county of Haliburton county in Ontario" and that, in addition, he had a year's experience working for a farmer in Regina before his family headed out to their homestead." 
James Cooper ${ }^{25}$ also mentioned that he had been born and raised on a farm in England and had one year of experience of working on a Manitoba farm. Similarly, Edmond Cugnel ${ }^{26}$ had been raised and worked on a farm in France before travelling to the Weyburn district of Saskatchewan. N. Scott Branscombe ${ }^{27}$ reported that he had lived on a farm with his family in the province of New Brunswick while John Dickey ${ }^{28}$ stated that he had been raised on a farm in Nova Scotia. Another respondent, Samuel Williams ${ }^{29}$ recounted his experience of being raised on a rented farm. While working with his father on a piece of land that his father had rented in the spring of 1885 near Muskoka, Ontario, he indicated that it had been his responsibility, as an 11-year-old boy, to harrow the field with oxen in order to get it ready for seeding.

Thirty-two respondents (or 17.9\%) indicated that instead of being born and raised on a farm, they had learned about farming practices by working as a paid labourer. Stanley Hickley ${ }^{30}$ reported that he had one year's experience working for a farmer and that he had looked after a farm alone during the winter of 1910-11 while Samuel Ellwood ${ }^{31}$ reported working on two different farms over the course of seven years. Harry Ford ${ }^{32}$ also worked as a farm labourer for two years from the age of twelve to fourteen. He then spent another five years on the same farm learning the trade of a wheelwright. Another respondent, James Tulloch ${ }^{33}$ indicated that he had been hired on as a farm hand in Scotland for four years and that once he had accumulated enough funds, he made his way to western Canada. George Bruce ${ }^{34}$ from Scotland, worked for various farmers in Manitoba in 1903. While in the town of Elgin, Manitoba, his duties included wheeling manure out onto the fields and spreading it. For two weeks work, he received $\$ 5.00$ in pay. When he worked for another farmer as a hired man, he was paid $\$ 25.00$ per month until the work of threshing was done and then he was terminated. In a unique circumstance, Mrs. Jessie Cameron reported that both she and her husband "worked as a young married couple for a bachelor farmer at Arcola, Saskatchewan." They eventually homesteaded themselves in 1908 at Findlater, Saskatchewan ${ }^{35}$.

While the majority of respondents reported having experience with farm work, fortysix respondents $(25.9 \%)$ indicated that they had come to western Canada to homestead completely unprepared for homesteading as they had no farming skills whatsoever under their belts. As reported by twenty-five-year-old Albert Elderton ${ }^{36}$ on his situation.

I was an unadulterated greenhorn from England. And to show you how green a greenhorn I was, then living in the city 10 miles south of London, England and thinking I was soon to be a farmer boy in Canada, I put on my swanky leather leggings, all brightly polished and went out into the backyard and dug up the backyard garden. Just for experience, you know. Just for experience.

Frank Wilson ${ }^{37}$ also indicated that he had no prior farming experience as he had been a cabinet maker in England. He stated that he learned to farm by "trial and error and by starting in and making the best of it". Frank Baines ${ }^{38}$ also highlighted the fact the he had to learn by trial and error as well, "with large portions of the latter." 


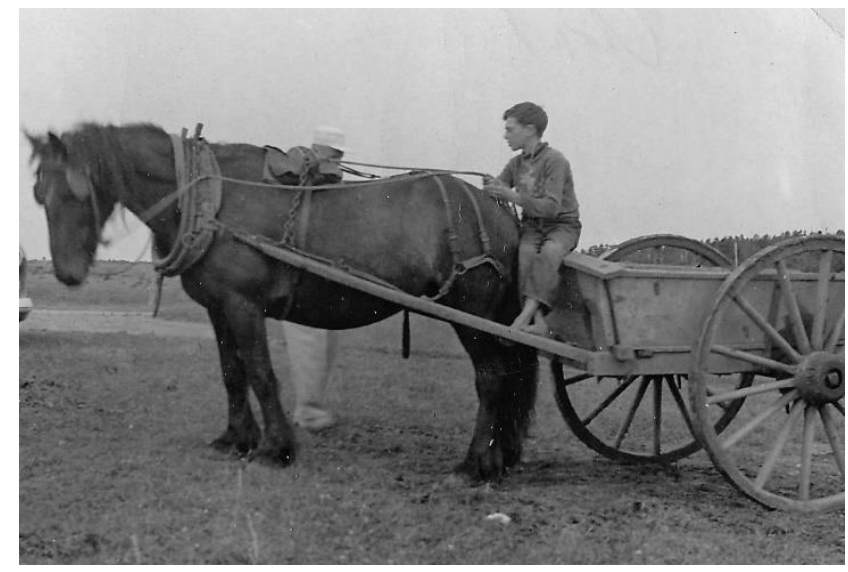

A young boy in the field with his horse and wagon (1911). ${ }^{39}$

\section{Working the Fields}

Given the imperative of breaking and cropping a certain number of acres within a certain period of time, immediate attention was paid by the homesteader and his family in readying the fields for seeding. In order to break the sod, or to turnover dirt that had previously been covered with trees, brush and weeds, settlers relied on farm animals and their own labour power to accomplish the task.

While 72 respondents (or 37.9\%) reported that they used a team of horses to plough the land, it was much more common for homesteaders to use a team of oxen. ${ }^{40}$ In fact, 82 respondents (or $43.3 \%$ ) indicated that they used oxen for this kind of hard labour. These animals, with their strong muscle power, were beneficial to settlers as they could pull a plough ${ }^{41}$ and break through roots and hard sod without too much difficulty. As indicated by Koozma Tarasoff $^{42}$ : "For starting the farm, the oxen were quite efficient." The only common problem with using these animals was that they were very independent animals and had minds of their own. As reported by George Hickley ${ }^{43}$ : "At times, they refused to pull. At anytime, if they wished to go to the stable, they went regardless of plough or persuasion of the driver." N. Scott Branscombe $^{44}$ faced a similar problem with his oxen. He wrote that one time, after feeding his oxen, "they put their tails over their back and ran away and you couldn't hold them and they would land you in a slough. The mud flew and everything else and I am telling you, there were no pet names going."

Frank Baines ${ }^{45}$ recounted another problem as his oxen wouldn't follow his direction for turning left or right. As he stated "Buck wouldn't gee and Bright wouldn't haw." Arthur Wheeler ${ }^{46}$ reported that his ox Mac "was the stubbornest, most unpredictable creature on four legs. My partner and I thought we would do some training so took him ...to snag logs out of 
the bush. We hooked him onto a tiny log, my partner holding the halter. Mac spotted the barn $1 / 2$ mile away and [he took off]. My partner hung on, the cart went flying and so did Mac." Joseph Wilson ${ }^{47}$ remembered how he was working with a walking plough when the oxen ran into a bee's nest. He indicated that he "had to let them go. They ran away and with their tails in the air and bees after them. Plow was smashed up when I got to them."

Frank Wilson ${ }^{48}$ also had his own reminisces about his oxen that he wished to share. As he wrote:

They were not very well broken so had quite a time getting them to pull a breaking plow. One would roll against the other and knock him out of the furrow, so after much trouble with him, I got a long narrow board and put nails in it and put it between them so when the middle one knocked into the furrow, one of the nails pricked him. When he first touched them, he did some fancy jumping but after a while they became real good at plowing.

Given the hard task of ploughing, Harvey Carson $^{49}$ indicated that he had set up a rigid system over the course of the day that would ensure a good day's work without tiring out the animals too much at one time. He indicated that: "Them and I used to start breaking in the morning around 2:00, breakfast at 6 o'clock. Start again at 7:00 and unhitched at 10:30. Hooked up again around 2:30 and broke until 6:00 p.m. I never stopped for rain as there were no mosquitoes while it was raining." 50

After the ploughing process was completed, the fields would need to be harrowed. The purpose of harrowing was to break down the large clumps of dirt into a workable tilth and to smooth the ground for seedbed use. Typically, a drag harrow or spike-tooth harrow was used by many respondents. These types of harrows were made of "wood or iron and contained rows of iron teeth. Two horses would be able to pull these types of harrows given that they were reasonably light, however, depending on the size of the harrow, it was often suggested that up to four farm animals be used in this process. ${ }^{51}$ While harrows could be purchased through the Hudson's Bay Company ${ }^{52}$ or the T. Eaton Company catalogues ${ }^{53}$, some homesteaders could not afford the cost of the equipment. As such, they would improvise and create their own harrow as was done by Lillian Miles ${ }^{54}$ and her family:

Harrows were made by driving railroad spikes through boards until we had about 5 or 6 rows on the boards. A team of horses would be hitched to the harrows. We made a drag by putting willows through the holes in a log and the brush end of the willow was left on to form a thick brush and this would be used after the harrows. Then a board was laid on the brush and stones put on the board to weigh it down and a man would stand on this board also to drive the team.

Many homesteaders reported their success in ploughing, harrowing, and readying their land for seeding during their first year of residency on the land. Seventy-eight respondents (or 
$44.3 \%$ ) reported breaking between one and ten acres with forty-five of those breaking exactly ten acres. Forty-eight (or 27.3\%) of respondents stated that they were able to break between eleven and twenty acres, while eighteen (or 10.2\%) broke between 21 and 30 acres in their first year. ${ }^{55}$ In their second year, forty-eight respondents (or 30.2\%) reported breaking between one and ten acres, while forty-one respondents (or 25.8\%) indicated that they broke between eleven and twenty acres. Twenty respondents (or 12.6\%) reported breaking between twenty-one and thirty acres. Similar results were found for the number of acres broken in the third year. Samuel Ellwood $^{56}$, for example, was fairly consistent in the number of acres that he broke year after year. He indicated that he broke 18 acres in his first year on his homestead, followed by 12 acres in the second year and 15 acres in the third, for a total of 35 acres broken over a three year period. Amanda Aikenhead ${ }^{57}$ reported that her family had similar results. They broke 10 acres the first year, followed by 15 acres in both the second and third years for a total of 40 acres. Frank Kusch ${ }^{58}$, however, was a bit more industrious with breaking his farmland as he indicated that he broke 10 acres in the first year, but broke 60 acres in the second and 75 acres in the third, for a total of 145 acres.

Unfortunately, there were some homesteaders who were not as successful as their counterparts. $^{59}$ Thirty-five respondents (or 18.6\%) indicated that they were not able to break and crop the required number of acres needed in order to gain title. For example, Weldon Lindeburgh ${ }^{60}$ reported breaking fifteen acres the first year, but none in the second and third years. William Leader ${ }^{61}$ stated that he was able to break 10 acres in the first year, none in the second, and five acres in the third. Similarly, Achille Godin ${ }^{62}$ broke 3 acres in his first year on his homestead, none the second year, and twelve in the third. No reasons were given by these respondents for why they were unable to complete the required number of acres as set out in the Dominion Lands Act regulations. ${ }^{63}$

Once the land had been broken, the homesteader had to decide on which crop he would initially seed on his land. The majority of respondents (80 or 39.5\%) indicated that they primarily grew wheat ${ }^{64}$, while 50 (or $24.6 \%$ ) reported growing oats. Twenty-three respondents $(12.3 \%)$ stated that they seeded their land with flax, while fewer numbers used barley or potatoes. Fifty respondents (or 24.6\%) reported planting a variety of different crops including wheat, oats, barley, speltz (hulled wheat), flax, field peas, rye, brome grass, corn, and alfalfa.

Respondents were also asked about the earliest date that they had seeded their fields. While one respondent (.9\%) tried his luck at seeding in February (an extremely cold winter month), the majority waited for warmer weather to commence. As such, forty-seven respondents (or 41.2\%) indicated that they seeded their fields in March, while fifty-six (49.1\%) seeded in April. Nine respondents (or 7.9\%) seeded in May ${ }^{65}$ with two respondents (or 1.7\%) planting their crops in June.

For those who seeded in the earliest years of homesteading, the work was physically exhausting given that the work was done manually. As mentioned by Lillian Miles ${ }^{66}$ : "All seed in the earliest years that my folks arrived (1886) was sewn by hand." Mrs. C.E. Diggle ${ }^{67}$ provided more detail when she explained how her father had spread the seed on their fields. "Father sowed seed with a tin container hung by straps to his shoulders. It was shaped to his body and held about a bushel. He scattered the seed with both hands as he walked." Instead of a tin container, some homesteaders put seed into an old flour sack that they carried with them, 
while others would tie a small sheet or blanket around their waist. ${ }^{68}$ They would pull the sheet in front of them making an improvised pouch in which they placed their seed. By doing so, it was convenient for the homesteader to grab handfuls of seed and distribute the seed in front of himself. When he walked on the seed, his feet would press the seed into the soil. ${ }^{69}$ Over time, homesteaders did see technological improvements which made seeding far more efficient. A mechanical distributing device, the wheeled broadcaster, was introduced where the seed would be thrown out "in a fan-shaped shower as it revolved". The grain would be carried in a hopper or knapsack carried by the homesteader and released into the device as needed. ${ }^{70}$

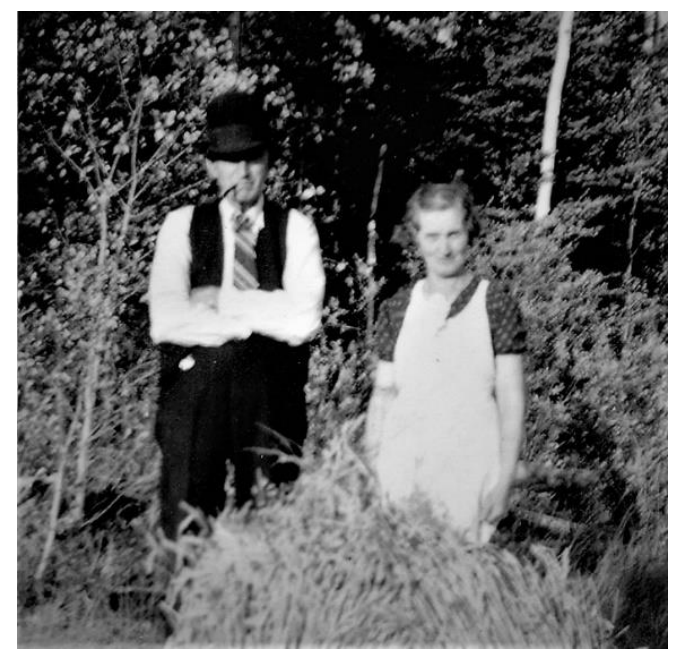

Two homesteaders, Joseph and Etta Biglow standing in front of some sheaves. n.d. ${ }^{71}$

Given the early months in which planting was completed, it was not surprising to find that the harvesting of crops took place in mid to late summer. Fifty-nine respondents (57.2\%) indicated that they threshed their crops in August while thirty-six respondents (34.8\%) reported undertaking this work in July. Eight respondents (8.0\%) stated that their fields were ready for harvesting in the month of September.

The process involved with the harvesting of grain was one that first began with the use of hand tools. Men would use the scythe (a heavy wood and metal "L" shaped device) while women used the sickle (a lighter wood and metal "C" shaped implement) to reap the grain. Both would swing their tools through the fields chopping down the tall stalks of wheat (or other crop) that was ready for harvesting. After all of the stalks had been cut, women and children would gather the stalks and tie armloads of them into sheaves. A number of sheaves would be placed together (each leaning on the other) to form a stook. Stooking ensured that the kernels were kept off the ground until the homesteader came by and collected them by using a hayfork and pitching them into the back of a horse or oxen-drawn wagon. ${ }^{72}$ The wagonload of stooks would then be taken to the barn for threshing. ${ }^{73}$ 
The purpose of threshing was to remove the kernels from the husks. Homesteaders would use a flail (a tool with two large sticks attached with a chain or piece of leather or rope ${ }^{74}$ and beat the kernels from the husks until the kernels came loose. The kernels would then be collected and winnowed. Winnowing was used to clean the kernels from any chaff that existed. Two individuals would hold two corners each, of a piece of canvas. The kernels would be placed onto the middle of the canvas and the two people would bounce the canvas up and down. The chaff would separate from the kernels and sometimes blow away if there was a breeze. ${ }^{75}$ The remaining (clean) kernels were once again collected and shoveled into sacks or loaded loose into the back of the wagon, ready to be taken to the grain elevator.

A number of respondents remembered their early years of harvesting and their use of hand tools. Robert Widdess ${ }^{76}$, for example, indicated that his family always used scythes and sickles during their first years on the homestead. Koozma Tarasoff ${ }^{77}$ indicated that his family worked the fields by hand as well, however they used a slightly different technique in their operations. As he stated:

We cut the grain by hand with a scythe. Then we raked it with hand rakes (wooden) and gathered into a pile for transporting by a hay rack. Then we prepared a level ground for threshing (wet the ground with water some mixed some clay and chaff), then the ground was rolled with wood rollers. Then horses and beaters were used to trample the grain. Wheat was cleaned by the wind and by screens.

Another respondent, Lena Purdy ${ }^{78}$, recounted her family's harvesting practices when she reported: "Father cut that first 8 acres with a cradle, formed by hand, and threshed it with a flail he made....He kept some oat sheaves for feed, but threshed what he needed for seed."79 Lillian Miles ${ }^{80}$ indicated that on her homestead: "The wheat was cut by hand with a sickle. This was done for about 2 years. While one was cutting, others stooked the grain and it was put into stacks. Our first threshing was done with horses tramping it out with their feet."

Eventually, new threshing technology using an inclined treadmill was developed which relied more heavily on animal power. Horses were hooked up to the machine and the treadmill would begin turning. Due to the incline, the horses would automatically begin to walk forward. Attached to this treadmill was the threshing machine, where men would throw pitchforks of sheaves into the machine. As the horses walked, the mechanism separated the husks from the kernels, with the kernels dropping down onto a platform underneath the threshing machine. ${ }^{81}$

Some respondents commented on the change in harvesting technology they had personally experienced during their early years on the farm. ${ }^{82}$ Elizabeth Duncan ${ }^{83}$, for example, indicated that her family first harvested with a scythe and cradle, but that as time went by, they eventually turned to using a horse-powered threshing machine. Another respondent, Mrs. Robert Wilson ${ }^{84}$, also commented on her family's switch in technology when she stated that: "The threshing was done by horsepower, about 10 or 12 horses in teams on a wheel with a driver in the centre who had a whip." John Dickey ${ }^{85}$ also indicated that he used a horse powered threshing machine during his years as a homesteader as did Richmond Bayles ${ }^{86}$. However, 
Richmond stated that the horse-powered threshing machine that they used was one that was shared by the community. Once one homesteader was done, the threshing machine was moved onto the next farm, until everyone's crops had been threshed. ${ }^{87}$

Following the threshing process, the homesteader would either store the grain in granaries that he had built on his homestead, send it to the local mill for processing, or it would be hauled away to the county elevator or to a loading platform on a railway siding. Lillian Miles ${ }^{88}$ recounted that in the late 1880 s, her family "used to haul grain to market with a team and wagon. [They] hauled it to the mill at Indian Head for making into flour and other products in the summer." She also mentioned that they hauled grain during the winter months on a sleigh to Balgonie. Like Lillian and her family, John Peacock ${ }^{89}$ reported that he hauled his grain to town during the warm or cold months of the year. To him, it all depended on the shape of the roads. As he stated: "If we had good roads in the winter, we would haul some grain, likewise in the summer. When the roads were good, we would do some hauling." Lena Purdy ${ }^{90}$ also indicated that her family preferred the winter for moving their grain as other work needed to be done around the homestead in the fall. Like Lillian's family, they used horses and a sleigh to transport their product. Frank Baines ${ }^{91}$ indicated that he also preferred the winter months, however he used a team of oxen, rather than horses, to pull his sleigh ten miles to Saltcoats. Edith Stilborn's family ${ }^{92}$ also transported their grain to such places as Wolseley, Indian Head, or Qu'Appelle, however each trip was a lengthy one, averaging about 35 miles. George Hickley ${ }^{93}$ also had a long way to travel as he indicated that he hauled all of his grain in the winter by sleigh over 40 miles (one way); an eighty mile round-trip..$^{94}$

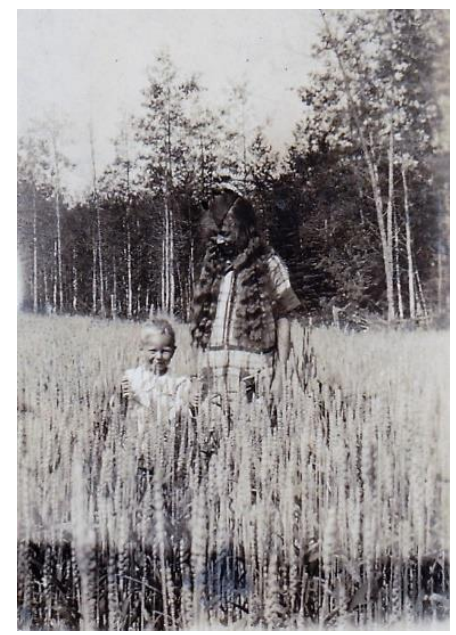

Two children standing in a wheat field $(1914)^{95}$ 


\section{Hazards, Pests and Other Challenges}

Each and every respondent had some sort of tale to tell about the hazards associated with homesteading life and crop production. At each turn, settlers were faced with a diverse assortment of problems, difficulties, dilemmas, and predicaments throughout the course of the year. Whether they were dealing with cutworms that destroyed gardens and crops, biting insects during the spring and summer months, or freezing temperatures during the late summer/early fall, each issue that arose had to be dealt with in some fashion by the homesteader and his family. A great amount of perseverance was needed to overcome each situation, as well as ingenuity and in some cases, humour, otherwise the circumstances could become so dire and disheartening that many settlers would be willing to admit defeat and relinquish the homesteading life. Regardless of how each homesteader faced each individual problem, frustration levels tended to be high. As succinctly expressed by Albert Elderton ${ }^{96}$ :

I have experienced them all, with varying degrees of severity and damage in each case....We had lots of blizzards, and lots of drought, some hail even up to $100 \%$ damage and down to slight. Frost, wind and dust, more than you could shake a stick at. Cutworms, hoppers, sawflies, skeeters, gophers, oodles and oodles, blast them!

While many respondents such as Albert listed a number of problems with homesteading, some discussed, in greater detail, particular aspects of their individual experiences. For example, Amanda Aikenhead ${ }^{97}$ elaborated on the devastating consequences associated with hail storms. As she stated: "In the year 1899. The worst hail storm ever known occurred in all the Melfort district. Cattle were killed and all the crops were battered to the ground. Farmers had to go near Prince Albert for feed for stock, gardens were battered to the ground, some came again. Carrots, beets, underground vegetables." Jessie Cameron ${ }^{98}$ also highlighted her experiences with hail as she indicated that: "We were completely hailed out. We watched the storm coming. It seemed to be from two directions south-west and north-west and the storm joined together a short distance from our land. I had 45 choice grey Plymouth Rock chickens, just about ready to use for meat, and they huddled on the ground, west of the barn and were all killed with the hailstorm. Alice Downey ${ }^{99}$, also reported her family's situation after a hail storm. As she indicated:

We had a terrible wind in 1910 on July $3^{\text {rd }}$. Hail that cut the crop down which was very poor to start with. And blew it all away. We just threshed some seed and had one wagon load of wheat to sell. That was our hardest year as our money was all gone to five dollars in the bank. Our animals nearly starved to death as we had so little feed. ${ }^{100}$ 
While hail damage could cause considerable damage, early frost was also a curse on those who relied on their harvest for income. According to Edith Stilborne ${ }^{101}$, frost was the greatest hazard that her family had ever experienced as crops were entirely wiped out. Such was the situation with James Tulloch ${ }^{102}$, who also indicated that his oat crop was completely destroyed in 1907. In addition, he exclaimed about how the early cold had left many of his pigs lame. Alfred Gibson ${ }^{103}$ discussed this same frost in his memoirs. As he stated:

The worst crop disaster was in the year 1907 when a heavy frost came when the wheat was in the milk stage in August. None of us realized how bad the damage was until cutting started. Some farmers then plowed fireguards around their fields and burned the crop. Others did the same after cutting. Some sold hay rack loads of wheat sheaves for fifty cents to those lucky enough to have cattle to feed.

Joseph Wilson ${ }^{104}$ remembered the severe frost that he experienced in 1909. He wrote: "I had 200 acres frozen in 1909, I think it was. I had the threshing machine work one day and they hardly cleared expenses so I burned all the rest as I had no stock to feed it to."105

Another threat that put many lives at risk on the western prairies were the prairie fires. Such fires could spread for miles and in combination with strong prairie winds and dry grasses which burned quickly, such fires could overtake a homestead within minutes. ${ }^{106}$ Prairie fires could be started by lightning storms as reported by John Peacock. ${ }^{107}$ "The worst prairie fire I saw was set by a dry lightning storm. We had our buildings well fireguarded from the west as that was the direction of the prevailing winds but this fire swept up on us from the south east and we had to do some quick work to save our buildings." Other prairie fires could ignite by sparks thrown from farm machinery. Arthur Wheeler ${ }^{108}$, for example, reported that: "Prairie fires were very bad in the early days as there was much old prairie grass and if a fire started, it swept for miles uninterrupted, burning haystacks and homes. One bad fire was started by a steam engine while threshing on a very dry day and burnt granaries of wheat and crops." Another respondent, Harry Ford ${ }^{109}$ indicated that prairie fires were severe and a common event given the sparks set off from trains as they rolled over the rails."

The devastation caused by prairie fires were recounted by a number of different respondents. Edith Stilborne ${ }^{110}$, for example, wrote that "prairie fires took their toll every autumn" particularly in the early years of homesteading. The grasses would be dry and very few fireguards had been created through the breaking of land. However, people did build fireguards around their homes and barns for protection." Elizabeth Duncan ${ }^{111}$ also remembered "lots of prairie fires but the only harm they done to us was burn the pasture and some hay stacks." Amanda Aikenhead ${ }^{112}$ stated that: "Prairie fires destroyed a lot of hay in 1896 and farmers had to make hay over again." Lena Purdy ${ }^{113}$ indicated that during "the fall of 1885 there was a terrible prairie fire extending over a large part of the prairie between the Qu'Appelle Valley and the C.P.R. We saved our buildings and stacks but felt the loss of the pasture, especially in " 86 when it was very hot and dry." 
Others faced more serious circumstances when faced with a prairie fire. James Tulloch ${ }^{114}$, for example, wrote that: "I had a fire that burned down my shack and one horse stall and a large amount of hay. As the nearest homesteader was about 2 miles away, I had to live in a tent until spring.... The worst prairie fire was in the fall of 1895. Many settlers were burnt out. They were forced to sell out their stock." Similarly, Richmond Bayles ${ }^{115}$ was also burnt out by a prairie fire. He indicated that "all the fireguards we plowed were of no avail. It took weeks before we located all our stock." Sydney Chippenfield ${ }^{116}$ also commented on the prairie fire that affected his homestead in 1896. He wrote that it was "a disastrous prairie fire. We lost all grain, feed, stables. 11 good pigs, harness etc."

Along with unsettling climatic conditions and random, unpredictable circumstances like prairie fires, homesteaders also had to deal with insect infestations. Some insects could destroy crops and gardens and kill animals, while others were irritants to those who came in contact with them. One of the primary irritants on the prairies that respondents noted was the grasshopper. Grasshoppers would eat all vegetation above ground and as such, wipe out gardens that the homesteaders relied on for nourishment and crops for harvesting. According to Barry Potyondi ${ }^{117}$, the "grasshoppers were so numerous from 1868 to 1875 , that some people believed they had become permanent colonists and that field crops would never again be grown successfully."

More often than not, discussion surrounding these insects highlighted the techniques of how to kill them off en masse. Mrs. Robert Wilson ${ }^{118}$, for example, explained how the

grasshoppers were terrible and my husband went all over organizing gangs of farmers to mix and spread poison. At home, we tried spreading straw around the fields and burning it off early in the mornings. This got a lot. I kept my chickens in the far corner of the yard and early in the morning, I would let them out and then take a stick and beat the caraganas round the yard. The grasshoppers climbed into them over night and this made them hop down and the chickens ate them up.

Albert Elderton ${ }^{119}$ also advised how he controlled the grasshopper population on his homestead. As he wrote:

Control for hoppers was the poisoned bait method (sawdust and bran), put in a hopper and distributed by the bait falling on to a sort of a fan or blade spreader revolving under the hopper. Some drove this contraption by a belt which took in power from the hub of a wheel on a wagon pulled by horses (the hopper and bait being in the wagon). Later came the various types of sprayers using poisoned water.

Charles Bray ${ }^{120}$ also highlighted his concerns with the grasshopper population on his homestead. He indicated that he had to poison grasshoppers all over the farm one year in order to protect his plants. ${ }^{121}$ 
Along with grasshoppers, another destructive insect was the cutworm. Cutworms were caterpillar-like insects that tended to eat vegetation below the ground and near the surface. N. Scott Branscombe ${ }^{122}$ reported that the cutworms were severe on his land and that he didn't know what to do about the problem whereas Thomas Drever ${ }^{123}$ found a unique solution:

I remember one year there were a number of patches in one-quarter section eaten by cutworms and the following year, nearly all of the field was destroyed. As there were some seagulls around, I thought I would help feed them, so went out and harrowed the ground. The birds followed for a while, hundreds of them. This I did every day as long as the birds would feed, with the result that the following years there wasn't any sign of a cutworm.

Other insects that bothered animals and homesteaders alike were sandflies and bulldog flies. Many respondents, such as Amanda Aikenhead ${ }^{124}$ reported that "sand flies attacked the cattle and horses". Mrs. Robert Wilson ${ }^{125}$ indicated that the sand flies were so numerous that her family had to put pieces of sacking over the noses of their horses and cows in order to keep the flies off of them. Harry Ford ${ }^{126}$ also highlighted the problems with fly infestations as he wrote: "We had flies in the fall of one year that got in the eyes of the oxen until they could not see to travel." Rather than discussing the frustrating conditions associated with sandflies, Mrs. C.E. Diggle ${ }^{127}$ mentioned the more serious encounters she had with bulldog flies in her memoirs. As she reported: "There was a small black fly that caused the death of cattle in hot weather. Bulldogs - over half an inch long and grey black. [They] bit viciously as I well remember when I rode the horse in bare legs while scuttling the potatoes."

Along with dealing with biting flies, respondents also drew attention to the harshness of life with mosquitoes. Many respondents, particularly those who came from Europe, were unaware of the ferocity of the mosquito population on the western prairies and as such, were completely unprepared for the miserable conditions that they faced. In the early days of homesteading, the air would be thick with the large gray blood-sucking biters. As Joseph Wilson ${ }^{128}$ pointed out, "the mosquitoes...were so thick you could slap the oxen on their sides and kill thousands and have lots on your hand." Another respondent, Howard Irvine ${ }^{129}$ also wrote that: "In the early years, they were bad. I have seen them so bad, that towards evening, you couldn't see what colour a horse was." In a similar vein, Edith Stilborne ${ }^{130}$ reported that: "Mosquitoes were terrible. They caused the oxen to go frantic, so that would bolt to a bluff or slough where they could brush or wash them off. We made big smudges and would unhitch the oxen and drive them to the smudge. The oxen would be literally covered so one could not tell their color." Mrs. C.E. Diggle ${ }^{131}$ also wrote about the mosquito problem. As she indicated, "Mosquitoes were in the millions of course with all the sloughs, alkali and soft water. Probably about 2 dozen sloughs on our section. Often animals had to stay all day at the smudge." Arthur Wheeler ${ }^{132}$ also highlighted the same concerns as he stated that "Mosquitoes were terrible especially in 1907 when water levels were high....I remember one farmer breaking land with a pail holding a smudge on the plough handles. Some days it was impossible to work. 
Even at night, there was no escape from the biting insects. As set out by N. Scott Branscombe ${ }^{133}$ : "The mosquitoes were the only thing that you were sure of, were they ever big and the buzz of those things at night when you tried to sleep and the next morning, you looked as though you had measles." Albert Elderton ${ }^{134}$ emphasized his relationship with the mosquitoes in the following way:

Skeeters we simply controlled by being slap happy and it took a lot of slaps in a bad year, I'm telling you. Oh sure, we made smudges for the poor animals to get a little relief. We also cursed Mephistopheles, Beezlebub, Old Nick, et al. for persecuting us with the blighters, but it didn't seem to help much.

Another source of constant irritation on the prairies were the gophers and the garden and crop destruction that they could cause if their populations were left uncontrolled. As reported by Edith Stilborne ${ }^{135}$ : "Gophers took their share (or more) of the crops each year while Richmond Bayles ${ }^{136}$ indicated that with "gophers, it used to be a fight between us who should take the crop. The government supplied us with poison which we mixed with wheat and placed it in their holes." Albert Elderton ${ }^{137}$ reported that he not only relied on poison to kill the gophers on this land but that he also used traps. Lena Purdy ${ }^{138}$ also mentioned her family's reliance on using traps as she wrote that she and her sisters would literally catch hundreds of gophers in traps. Jessie Cameron ${ }^{139}$ described her homesteading life with gophers when she stated that:

Gophers were a bugbear. My husband bought me a 22 rifle to keep them out of the garden. Gardens meant so much to the homesteaders for winter vegetables. I had to learn to handle the 22 and would go out to the garden and see gophers scampering all over. They were quite safe in my presence. After I'd shoot, the gopher would stand up in the same place on his hind legs and with front paws chewing away at my garden stuff and just seem to say to me "Try again novice!". I longed for the day I could tumble them over and I kept practicing and was able, before long, to tumble over a good many of them to save my garden.

Mrs. Robert Wilson ${ }^{140}$ indicated she had help in tracking down gophers on her land. She reported that "the gophers were poisoned, trapped and shot with a 22... "My dogs were always very helpful. One could even come and tell me to bring the gun if he had a gopher cornered. Other respondents used other tactics to kill the pests. As set out by John Peacock ${ }^{141}$, "they were so tame you could make a loop with an ordinary length of bag string, set it in a gopher hole and lay down an arm's length from the hole and have a gopher in five minutes." Another respondent used a different tactic. Mike Bloodoff ${ }^{142}$ indicated that his family "used to drown many of them with water." 
As well as having insects and gophers to contend with, homesteaders also had to deal with a vegetative menace which attacked their crops - weeds. According to a farm management expert, James Fletcher ${ }^{143}$, farmers on the western prairies experienced incredible financial losses "owing to the presence of such a large percentage of foul seeds" that were found within the crops of the early 1900s. ${ }^{144}$ He went further and explained why weeds were so detrimental to homesteader's crops. Weeds, he said, "robbed the soil of the plant food intended for the crop and also of its moisture." 145 This had the result of increasing the effects of drought. He also indicated that weeds would choke out crops and take their place as they were stronger and more plentiful and that they would attract insects like cutworms which, as discussed earlier, had negative effects on crop yields. In addition, some weeds were harmful to farm animals as they were poisonous if eaten. Other weeds caused painful sores or cuts on the skin on the animal if the animal came into contact with the weeds. ${ }^{146}$

As recounted by the respondents, the prairies were free of weeds during the initial years of homesteading, however they grew in variety as time went by. N. Scott Branscombe ${ }^{147}$, for example remembered how pristine Saskatchewan was in the late 1800s when he stated that: "It was all prairie and no weeds". Albert Elderton ${ }^{148}$ also reminisced about how clear the land was in the early years and how it became polluted with weeds as larger numbers of homesteaders arrived. As he indicated, there were "none at first because the land was virgin prairie. Later on, as one of my old farmer friends used to say 'Every dang type variety and species known in the science of botany and some as ain't [began to grow in the fields]. Stinkweed, Tumbleweed, Russian thistle, Yellow Mustard, Wild Oats most common." Kate Stirling ${ }^{149}$ also commented on her family's weed situation. As she wrote: "We had only pigweed when we came here. Until the farmers came, then we gradually got most every kind including Russian thistle, Canadian thistle, mustard and stink weed." ${ }^{150}$ James Tulloch ${ }^{151}$ also recounted the weed problem in his fields: "The summer of 1906, ball mustard in a field of flax on spring breaking. I got wild oats in 1907. The Saskatchewan Valley Land Company bought them in through feed oats shipped in from the States." Amanda Aikenhead's family ${ }^{152}$ also suffered with a number of different weeds. As she stated: "Stinkweed, Lamb's Quarters, Pigweed, Mustard, Sow thistle, Ball mustard. Some blamed the eastern Ontario farmers for bringing them. There was not a dandelion to be found in this part for years; now we are overrun with them."

Not every respondent viewed all weeds in a negative fashion. Some saw the benefits of growing weeds, particularly the ones that were edible. As set out by Mrs. C.E. Diggle ${ }^{153}$, pig weed (also known as Lamb's Quarters) was a favourite of her family during their meal times. Edith Stilborne ${ }^{154}$ also mentioned how she and her family also enjoyed eating this weed. As she stated: "When we arrived and started our farming operations in 1883, the only weeds were buckwheat and Lamb's Quarters. This latter weed was used as a green vegetable and tasted something like spinach, very good." Along with Lamb's Quarters, dandelion leaves and roots could also be eaten and were often used in salads. For those homesteaders wishing to make a hot beverage out of dandelions, they would roast or fry the leaves and roots, dry them, and then grind them. They would make their hot beverage by simply adding a tablespoon of the crushed dandelions to a cup of hot water. For those homesteaders wishing to make wine, they would collect the yellow blossoms into a gallon-sized pail, pour boiling water over them 
and leave them for five days. After this time, the mixture was strained and sugar was added to the liquid as well as the juice of lemons or oranges and a pound of chopped raisins. This mixture was boiled once again and put into a crock. A yeast cake placed on a piece of toast was laid on top of the mixture. After three days, the liquid was strained once again, and placed into jars or bottles. The wine was then aged for a year before drinking. ${ }^{155}$

For those homesteaders who were less inclined to see any advantage associated with weeds and wished to eradicate all weeds from their fields, the process would turn out to be a long, tiresome, and ongoing one. Typically, the homesteader would try to exterminate the weed before it reached maturity and spread its seeds. As mentioned earlier, children would often be asked to help with weeding in the fields. As recounted by Mrs. C.E. Diggle ${ }^{156}$ : "I remember about 1894, the first mustard. Father promised my brother and I a holiday if we would pull it all from the wheat field." In other instances, homesteaders resorted to deep trenching so that the roots were exposed to the sun and destroyed. Some homesteaders preferred to summerfallow where they would plough and harrow the weeds in the field early in the spring and then cultivate three or four more times before winter. This process would continuously expose the roots and eventually the weeds would be eradicated. ${ }^{157}$ Other respondents tried to rotate their crops in the hope of keeping the weeds at bay. For example, Robert Wilson ${ }^{158}$ and Frank Langley ${ }^{159}$ both seeded wheat in their fields for two years in a row, followed by a year of oats and then barley. Once done, they would then begin the process over from the beginning. Ida Desmoyers ${ }^{160}$ followed a different rotating system. Her family grew wheat one year, followed by a year of barley, then oats, and finally potatoes. Still others, such as Milton Campbell ${ }^{161}$, introduced clover into their weed-infested fields. Clover was a vigorous plant which not only choked out weeds, but provided a good pasture crop for farm animals. ${ }^{162}$

\section{Conclusion}

The lives of homesteaders and their families were challenging ones. Whether they were labouring to meet the requirements of the Dominion Lands Act by breaking and cropping land or whether they were trying to survive severe climatic conditions like hail or fighting insects, rodents, or weeds, homesteaders had to be adaptable, resilient, creative, and industrious. At every step in the process, with each day that passed by, homesteaders faced many new difficulties that they needed to overcome if they wished to remain on the land and stay in the province. As stated by Edith Stilborne ${ }^{163}$ : "All these things seemed to be taken in stride, as it were. Those who stayed accepted these things and did all they could to eradicate the menaces to comfort and success. Some became discouraged and gave up, went back East or to other parts, but many stayed and made the best of things as we did." Another respondent, Frank Kusch $^{164}$ showed the same spirit as Edith when he described the experiences of his own family. They had to rally against adversity and they felt pride in having done so. This is evident when Frank stated that: "We had some damage from grasshoppers, cutworms, frost, gophers, but on the whole we were lucky to have moved to Saskatchewan." Arthur Tilford ${ }^{165}$ expressed the same sentiment but in a more humorous way. As he said, the "mosquitos had planted the prairie atmosphere into my veins. I couldn't leave the prairies." Even Simeon Hiltz ${ }^{166}$, who 
highlighted the labourious years of fieldwork, did not regret his family's homesteading years in the province. "Heartaches, backaches, hardships, loneliness all helped to make a district and home which we would never want to leave."

A homesteader relied heavily on those around him, particularly his wife and children, to help him with work around the homestead. While such endeavours were arduous and timeconsuming, every family member took part in some aspect of homestead life, whether they were a young child or whether they were elderly. One respondent, Edith Stilborne ${ }^{167}$ stated that: "We all helped with the farming operations. My brother, who was five when we came from England, in 1883, helped with harrowing when he was eight, before he could guide the oxen to turn them, mother used to help him turn around at the ends of the row." Another respondent, Koozma Tarasoff ${ }^{168}$ remarked on the hard work done not only by his wife and children, but also by his elderly mother. As he wrote: "Two boys, wife and mother helped with the farming operations. My wife and sons helped me on the field binder work, threshing, and plowing." Charles Bray ${ }^{169}$ also acknowledged how all of his family members took part in their homesteading operation. As he reported: "We had a large family and all were good helpers on the farm" while George Hickley ${ }^{170}$ remembered how his wife helped with "haying and stoking sheaves when man-help was not available. She helped milk cows during busy times."

Every once in a while, neighbours would also pitch in to help. If a fellow homesteader became ill, neighbours would help with the farm work until he was back on his feet. Jessie Cameron ${ }^{171}$ recounted one such instance when her husband was ill with measles. A bee was held on their land during seeding time. As she stated: "Just about worried to death (both of us), when to our great joy and surprise a goodly number of neighbours came, our land was to be seeded - they completed the field in one day. They even had their own lunch with them." Arthur Tilford ${ }^{172}$ also remembered the community spirit that existed at the time. "The homesteaders always worked together and there were lots of bees to help someone out. Everybody was in the same boat and helped each other. Some farmers would be so sick, there would be 5 or 6 neighbours, helping seeding." Similarly, James Cooper ${ }^{173}$ also said that "there was always help for building and for threshing. Sometimes we had haying bees, also when a farmer was sick in seeding or harvesting, the neighbours would turn in to take care of his crop."

Adversity bonded these homesteaders together. Even though hardships were placed in their path, many strove to overcome the problems and made lives for themselves and their families on the western prairies. They took pride in their accomplishments and in fact, came to appreciate those exhausting and arduous first years on the land. As reminisced by N. Scott Branscombe ${ }^{174}$, it was during those homesteading years that he "felt like a million", working and living on land that was to be his own. Labouring side-by-side with their family members, homesteaders appreciated the work of their wives and children as they toiled in the fields. With their assistance, land was broken and cropped, the Dominion Lands Act regulations were met, and many families were well on their way to achieving their goal of gaining title to 160 acres of homestead land in Saskatchewan. 


\section{NOTES}

${ }^{1}$ Dominion Lands Act, 1872 (Canada).

${ }^{2}$ A housing condition was also included which indicated that homesteaders were required to construct a habitable house on the land within the same two-year timeframe.

${ }^{3}$ Regulations were changed in that a habitable home had to be built within six months after entering the land.

${ }^{4}$ Even with ongoing revisions to the Act, hundreds of thousands of people registered for homesteads. By 1910, the total number of registrations was 389,332. In 1911, another 44,273 applied for homesteads. See Grant MacEwan, Harvest of Bread (Saskatoon: The Western Producer, 1969).

${ }^{5}$ For more information regarding the Dominion Lands Act and amendments, see K.N. Lambrecht, The Administration of Dominion Lands, 1870-1930 (Regina: Canadian Plains Research Center, 1991).

${ }^{6}$ For a discussion of the division of labour by age and sex on homesteads, see Rollings-Magnusson, S., Heavy Burdens on Small Shoulders: The Labour of Pioneer Children on the Canadian Prairies. (Edmonton: University of Alberta Press, 2009).

${ }^{7}$ It should be noted that Saskatchewan entered into Confederation in 1905. Prior to that time, the province was part of the North-west Territories.

${ }^{8}$ Given the methodology and the lack of a representative sample, it is impossible to generalize the results of this study to the entire pioneer population. However, the qualitative and quantitative information that was obtained is important as it provides information unique to pioneering life.

${ }^{9}$ One survey was unusable as no answers had been provided. As such, it has not been included in the total count.

${ }^{10}$ Unfortunately, the questionnaire did not include a question relating to the respondent's country of origin. However, it is interesting to note that approximately 1.3 million people moved to the western Canadian provinces between the years 1881 and 1911. Whether these migrants were from Quebec, Ontario, Newfoundland, or the Maritimes, or whether they were immigrants from England, Germany, Poland, the Ukraine, Russia, Switzerland, Belgium or the United States, many were motivated to move to Canada for the opportunity to own free land. Fifth Census of Canada (Ottawa: Canada: Government of Canada, 1911).

${ }^{11}$ Saskatchewan Archives Questionnaire, File \#2180, Mrs. C.E. Diggle.

${ }^{12}$ SAQ, File \#2204, Richmond Bayles.

${ }^{13}$ SAQ, File \#2197, Herbert Anslow.

14 SAQ, File \#2255, Joseph Wilson.

${ }^{15}$ SAQ, File \#2338, Albert Elderton.

${ }^{16}$ Last Mountain Lake is located in south central Saskatchewan.

${ }^{17}$ SAQ, File \#2200, John Dickey.

18 SAQ, File \#2195, Mary Brownridge.

${ }^{19}$ Advertisements, brochures, pamphlets as well as agents were located in various centers across western and eastern Europe. Their purpose was to attract and encourage people to emigrate to western Canada. See Daniel Francis, Selling Canada: Three Propaganda Campaigns that Shaped the Nation (Vancouver: Stanton and Dosil Publishers, 2011).

${ }^{20}$ SAQ, File \#2198, Martin Duesterback.

${ }^{21}$ SAQ, File \#2177, Frank Baines.

${ }^{22}$ SAQ, File \#2184, Edith Stilborne.

${ }^{23}$ Smaller numbers of respondents reported other reasons for relocating to a particular area in Saskatchewan. Three respondents, Charles Baker Hastings (SAQ, File \#2229), Winnifred Taylor (SAQ, File \#2240), and George Almond (SAQ, File \#2258) all indicated that they and their families came with the Barr colonists from London, England and settled in Lloydminster, Saskatchewan. Another respondent, George Arthur Hartwell (SAQ, File \#2174) and his family came with a group who formed themselves into what became known as the Primitive Methodist Colony in Pheasant Forks, Saskatchewan while Koozma Tarasoff (SAQ, File \#2215), a Doukhobor, reported that he and his family were persuaded to move from their mother country of Russia to Saskatchewan when they learned that three block settlements for Doukhobors had been established in the province.

${ }^{24}$ SAQ, File \#2375, John Peacock. 
${ }^{25}$ SAQ, File \#2230, James Cooper.

${ }^{26}$ SAQ. File \#2225, Edmond Cugnel.

${ }^{27}$ SAQ, File \#2244, N. Scott Branscombe.

${ }^{28}$ SAQ, File \#2200, John Dickey.

${ }^{29}$ SAQ, File \#2189, Samuel Williams.

${ }^{30}$ SAQ, File \#2353, Stanley Hickley.

${ }^{31}$ SAQ, File \#2233, Samuel Ellwood.

${ }^{32}$ SAQ, File \#2234, Harry Ford.

${ }^{33}$ SAQ, File \#2208, James Tulloch.

${ }^{34}$ SAQ, File \#2245, George Bruce.

${ }^{35}$ SAQ, File \#2224, Mrs. Jessie Cameron.

${ }^{36}$ SAQ, File \#2338, Albert Elderton.

${ }^{37}$ SAQ, File \#2242, Frank Wilson.

${ }^{38}$ SAQ, File \#2177, Frank Baines.

${ }^{39}$ Author's personal collection.

${ }^{40}$ Cost may have also been a factor as a yoke of oxen cost $\$ 100$ to $\$ 150$, while a team of horses cost $\$ 300$.

Ernest Ingles, Some Aspects of Dry-Land Agriculture in the Canadian Prairies to 1925 (Calgary: University of Calgary Press, 1973.) Some homesteaders could not afford a full team of oxen or horses. As such, they had to use what was available to them. As recounted by respondent Harry Ford: "The most peculiar sight [he ever saw] was a farmer plowing with a cow, ox, bull, horse and a mule" (SAQ, File \#2234). Other respondents reported using teams of mules or teams made up of a combination of mules and horses. Grant McEwan, in his book Power for Prairie Plows, related the story of a Saskatchewan homesteader who hitched himself up to the plow alongside his horse. He was the replacement for the second horse that had died.

${ }^{41}$ When respondents discussed ploughing in the early years of homesteading, they were referring to a walking plough which was drawn by a team of two horses or two oxen. It was guided by the homesteader who held onto the two handles of the plough. To control the animals, he would hang onto the reins or place the reins around his body. Eventually, the walking plough was replaced by the sulky plough. The sulky plough was far easier on the homesteader as the end of the plough was mounted on two wheels and had a seat for the homesteader to sit on. As such, the homesteader could ride on the plough rather than having to walk the fields. See J.W.G.

MacEwan ad A.H. Ewan, General Agriculture (Toronto: Thomas Nelson and Sons Limited, 1939).

${ }^{42}$ SAQ, File \#2215, Koozma Tarasoff.

${ }^{43}$ SAQ, File \#2353, George Hickley.

${ }^{44}$ SAQ, File \#2244, N. Scott Branscombe.

${ }^{45}$ SAQ, File \#2177, Frank Baines.

${ }^{46}$ SAQ, File \#2312, Arthur Wheeler.

${ }^{47}$ SAQ, File \#2255, Joseph Wilson.

${ }^{48}$ SAQ, File \#2242, Frank Wilson.

${ }^{49}$ SAQ, File\#2261, Harvey Carson.

${ }^{50}$ While Harvey Carson was aware of the amount of work that his animals could handle, others were less sympathetic or lacked knowledge about workload. As set out by Grant MacEwan, some animals were overworked as he stated:

Too often, the overtaxed animals fell victim to disease and died. Swamp fever accounted for thousands of horse losses. Death may have been a blessed relief for the overworked brutes, but their passing left the bereaved homesteaders in positions of helplessness. See Grant MacEwan, Power for Prairie Plows (Saskatoon: Western Producer, 1974) 2.

${ }^{51}$ J.W.G. MacEwan and A.H. Ewan, General Agriculture, 19.

52 The Hudson's Bay Company Autumn and Winter Catalogue, No. 58, 1910-11 (Winnipeg: Watson and Dwyer Publishing, 1977). 
${ }^{53}$ The T. Eaton Co. Limited, Spring, Summer, Fall and Winter Catalogue, 1901. (Toronto: The Musson Book Company, 1970). In 1901, the lowest price for a harrow was $\$ 14.25$.

${ }^{54}$ SAQ, File \#2194, Lillian Miles.

${ }^{55}$ The number of crops varied depending on the geography of the area. If there were few trees on the property, then clearing, breaking and cropping could be accomplished more quickly. If the homestead included hundreds, if not thousands of trees and shrubs, then it would take more time to clear, particularly since roots also needed to be pulled out of the ground. In this case, far fewer acres would be completed each year.

${ }^{56}$ SAQ, File \#2233, Samuel Ellwood.

${ }^{57}$ SAQ, File \#2216, Amanda Aikenhead.

${ }^{58}$ SAQ, File \#2181, Frank Kusch.

${ }^{59}$ According to statistics, quite a number of individuals were not able to successfully homestead and gain title to their land. During the period between 1894 and 1912, there were 153,261 cancellations across the prairie region and British Columbia. Separate figures were reported by province after 1912 and in the case of Saskatchewan, it is interesting to note that the cancellations amounted to at least fifty percent of recorded entries each year up to the 1930s. See M.C. Urquhart and K.A.H. Buckley, Historical Statistics of Canada (Toronto: The MacMillan Company of Canada Ltd. 1965) Series K34-41.

${ }^{60}$ SAQ, File \#2192, Weldon Lindeburgh.

${ }^{61}$ SAQ, File \#2193, William Leader.

${ }^{62}$ SAQ, File \#2201, Achille Godin.

${ }^{63}$ Grant MacEwan, in his book Harvest of Bread, provided a reason for why homesteads failed in the late 1800s. He explained that the 1880s were very dry years and as a result, many homesteaders became discouraged and either cancelled their registration or abandoned their land. For others, it was possible that the land that they chose to homestead on was unsuitable for farming in that it was too sandy, salty (from alkali), hilly, or contained too many sloughs. There may have been too many boulders or rocks to move or too many large trees (and roots) to eliminate. Another reason could be that the homesteader did not have enough labour power to finish the task. As noted in this paper, many of the respondents were reliant on family members to help them in the fields. If they were alone, they may have found the amount of work overwhelming. If they could not afford animal power, then the field work would have been nearly impossible to complete. (Saskatoon: Western Producer, 1969).

${ }^{64}$ Many homesteaders grew wheat given that it was in demand on the export market. See Vernon Fowke (The National Policy and the Wheat Economy. Toronto: University of Toronto Press, 1957). This demand becomes clear when comparing 1880 and 1890 production figures. In 1880, 57,000 acres had been seeded with wheat across the western prairies and one million bushels had been harvested. In 1890, 860,000 acres had been seeded and 16,459,000 bushels had been harvested. See Grant MacEwan, Harvest of Bread.

${ }^{65}$ It was interesting to note that even though May was considered to be a warmer month, Mrs. Robert Wilson indicated that while seeding, they were hit with a late winter blizzard and as a result, got "stuck in a snowbank" (SAQ, File \#2203).

${ }^{66}$ SAQ, File \#2194, Lillian Miles.

${ }^{67}$ SAQ, File \#2180, Mrs. C.E. Diggle.

${ }^{68}$ See Grant MacEwan, Harvest of Bread.

${ }^{69}$ See Grant MacEwan, Harvest of Bread

${ }^{70}$ See J.W.G. MacEwan and A.H. Ewan, General Agriculture, 26. The next technological invention, after the wheeled broadcaster, was the seed drill. In this case, "the grain is contained in a box or hopper with wheels at either end; the grain is passed through ports in the same way as in the wheeled broadcaster, but instead of being released to fall to the ground, is delivered into tubes, which convey it to a furrow dug by discs and filled in after the seed is deposited" J.W.G. MacEwan and A.H. Ewan, General Agriculture, 26-27.

${ }^{71}$ Author's personal collection.

72 There were two other reasons why the sheaves were stooked. As discussed by Buller, stooking sheaves lessened weather damage to the grain. If stooking had not taken place and the sheaves were left lying in the fields, it is likely that the grain would rot if it rained. By standing the sheaves upright, the grain was protected from the ground. The second reason for stooking is that after cutting the stalks, the grain in the heads of the stalks would continue to fill out and mature. A.H. Reginald Buller, Essays on Wheat (New York: The MacMillan Company, 1919) 46. 
${ }^{73}$ Some respondents indicated that they used binders. Binders were machines that would bind the sheaves into bundles using twine. The bundles would be set up in piles (known as shucks) so that they could dry out. Later, the homesteader would pick up these bundles with a bundle rack and then take them back to the barn where the bundles would go through a threshing machine. (These machines would have been far more expensive than the hand tools that most homesteaders used at the time.) One respondent, Kate Stirling (SAQ, File \#2214) wrote that and her family had used a binder when working the fields. Another respondent, Lillian Miles (SAQ, File \#2194), stated that the "whole community bought a binder and went from one farmer to another until everyone's harvest was in. Everyone worked methodically and in the best interests of all concerned." In a similar vein, Edith Stilborn (SAQ, File \#2184) remembered that "some early settlers came from Eastern Canada and bought binders with them. There were only a few, but they went the rounds, usually a man went and did the cutting for neighbours and others as the grain ripened."

74 George Hickley's family used a home-made flail that was made out of a "strong stick attached to a leather strap". See SAQ, File \#2353, George Hickley.

${ }^{75}$ For more information on the flailing and winnowing processes, see J. Sanford Rikoon's Threshing in the Midwest, 1820-1940 (Bloomington: Indiana University Press, 1988.)

${ }^{76}$ SAQ, File \#2186, Robert Widdess.

77 SAQ, File \#2215, Koozma Tarasoff.

78 SAQ, File \#2183, Lena Purdy.

${ }^{79}$ A cradle was a heavy wooden and metal tool that had a long metal cutter along with four tines (of similar length to the cutter). Some homesteaders preferred this tool as more area could be harvested in a shorter period of time.

${ }^{80}$ SAQ, File \#2194, Lillian Miles.

${ }^{81}$ Grant MacEwan, Power for Prairie Plows.

${ }^{82}$ For greater detail on the advances in farm machinery, see Randy Leffingwell's John Deere: A History of the Tractor (St. Paul, MN: Voyageur Press, 2006) and Massy-Harris, 1847-1947: 100 Years of Progress in Farm Implements (Toronto: Massey-Harris Company, 1947).

${ }^{83}$ SAQ, File \#2187, Elizabeth Duncan.

${ }^{84}$ SAQ, File \#2203, Mrs. Robert Wilson.

${ }^{85}$ SAQ, File \#2200, John Dickey.

${ }^{86}$ SAQ, File \#2204, Richmond Bayles.

${ }^{87}$ As noted by Adelman, the change in technology had a substantial impact on farming operations. As technology was developed at each step of the farming process, the new "machinery enhanced labour productivity... by increasing the amount of land that a single worker could cultivate and harvest" (pp. 282-83.). Adelman stated that machinery investments rose 10-fold between 1901 and 1916. In fact, even though "the average quarter-section farmer had twenty-two percent of farm capital tied up in machinery and horses", their productivity increased at the same time (p. 284). Between 1900 and 1915, "the value of farm production per person engaged in agriculture rose from $\$ 448$ to $\$ 1,738$ " (p. 289). See Jeremy Adelman, "The Social Bases of Technological Change; Mechanization of the Wheatlands of Argentina and Canada, 1890-1914," Comparative Studies in Society and History 34, 2, April (1992): 271-300.

${ }^{88}$ SAQ, File \#2194, Lillian Miles.

${ }^{89}$ SAQ, File \#2375, John Peacock.

${ }^{90}$ SAQ, File \#2183, Lena Purdy.

${ }^{91}$ SAQ, File \#2177, Frank Baines.

${ }^{92}$ SAQ, File \#2184, Edith Stilborne.

${ }^{93}$ SAQ, File \#2353, George Hickley.

94 Jessie Cameron (SAQ, File \#2224) indicated that hauling grain to market was an important time for herself and her children. She reported that when her husband took their grain to town and received payment, that he would buy items for his family. For instance, in the winter of 1910, he returned home with two house dresses for his wife. In the spring, he planned another trip where clothing would be purchased for their two young sons. Amanda Aikenhead (SAQ, File \#2216) reported that when her husband went to town with his load of grain, he would return with provisions such as flour, bran and oats which would last them a fairly long time.

${ }^{95}$ Author's Personal Collection. 
${ }^{96}$ SAQ, File \#2338, Albert Elderton.

${ }^{97}$ SAQ, File \#2216, Amanda Aikenhead.

${ }^{98}$ SAQ, File \#2224, Jessie Cameron.

${ }^{99}$ SAQ, File \#2350, Alice Downey.

${ }^{100}$ Another problem that homesteaders faced, but was not discussed in detail by the respondents was wind erosion. This occurred in areas where there was very little rainfall and high winds such as in Palliser's Triangle (a geographical area located in south-west Saskatchewan and south-east Alberta). The high winds would remove the most productive layers of soil from the land and prevent the germination of seeds. J.W.G. MacEwan and A.H. Ewan, General Agriculture.

${ }^{101}$ SAQ, File \#2184, Edith Stilborne.

102 SAQ, File \#2208, James Tulloch.

${ }^{103}$ SAQ, File \#2217, Alfred Gibson.

${ }^{104}$ SAQ, File \#2255, Joseph Wilson.

${ }^{105}$ Many crops in the early years of homesteading were ruined given that they had not yet matured before the frost set in. At that time, Red Fife wheat had been the crop of choice. It had been developed in 1820 by a Scottish immigrant who lived in Ontario, David Fife. Given its success in Ontario, it was widely believed that it would be similarly successful in western Canada. As such, in 1883, Red Fife wheat was planted in the western prairie provinces. However, serious problems occurred as the early frosts of western Canada ruined the wheat crops and made the grain unsalable. Farmers started pushing for wheat seed that had a shorter growing period of at least ten days. A new type was eventually developed by Dr. Charles Saunders; the Marquis wheat seed. It was released to the farmers in time for planting in 1910. See Grant MacEwan, Harvest of Bread. Respondents recounted their experiences with both Red Fife and Marquis wheat. As stated by Lena Purdy: "My husband like everyone else, had grown Red Fife wheat, and in the early years of this century, people began trying earlier varieties. We waited until Marquis was pretty well tested then switched to it. SAQ, File \#2183, Lena Purdy. ${ }^{106}$ According to Potyondi, prairie fires occurred every year during the homesteading era. In fact, he noted that in "1902 alone, over fifty fires were reported". (p. 71). He also elaborated on how dangerous the prairie fires were as they caused the death of people, horses, cattle, as well as crops. Barry Potyondi, In Palliser's Triangle: Living in the Grasslands (Saskatoon: Purich Publishing, 1995), 71.

107 SAQ, File \#2375, John Peacock.

108 SAQ, File \#2312, Arthur Wheeler.

${ }^{109}$ SAQ, File \#2234, Harry Ford.

${ }^{110}$ SAQ, File \#2184, Edith Stilborne.

111 SAQ, File \#2187, Elizabeth Duncan.

112 SAQ, File \#2216, Amanda Aikenhead.

113 SAQ, File \#2183, Lena Purdy.

114 SAQ, File \#2208, James Tulloch.

115 SAQ, File \#2204, Richmond Bayles.

${ }^{116}$ SAQ, File \#2179, Sidney Chippenfield.

117 Barry Potyondi, In Palliser's Triangle: Living in the Grasslands, 1850-1930,107-08.

118 SAQ, File \#2203, Mrs. Robert Wilson.

119 SAQ, File \#2338, Albert Elderton.

${ }^{120}$ SAQ, File \#2178, Charles Bray.

${ }^{121}$ Caterpillars were also a nuisance that ate all types of vegetation. Once again, respondents set out various methods of how they dealt with this type of infestation. Winnifred Taylor and her family, reported that: "We controlled them by using 1 cup coal oil in a large washtub of soapy wash water and applied by splashing along outer rows [of the crop] with a kalsomine brush, each morning for about a week" (SAQ, File \#2240).

122 SAQ, File \#2244, N. Scott Branscombe.

${ }^{123}$ SAQ, File \#2351, Thomas Drever.

${ }^{124}$ SAQ, File \#2216, Amanda Aikenhead.

125 SAQ, File \#2203, Mrs. Robert Wilson.

${ }^{126}$ SAQ, File \#2234, Harry Ford.

127 SAQ, File \#2180, Mrs. C.E. Diggle.

${ }^{128}$ SAQ, File \#2255, Joseph Wilson. 
${ }^{129}$ SAQ, File \#2318, Henry Irvine.

${ }^{130}$ SAQ, File \#2184, Edith Stilborne.

${ }^{131}$ SAQ, File \#2180, Mrs. C.E. Diggle.

132 SAQ, File \#2312, Arthur Wheeler.

${ }^{133}$ SAQ, File \#2244, N. Scott Branscombe.

${ }^{134}$ SAQ, File \#2338, Albert Elderton.

135 SAQ, File \#2184, Edith Stilborne.

136 SAQ, File \#2204, Richmond Bayles.

${ }^{137}$ SAQ, File \#2338, Albert Elderton.

138 SAQ, File \#2183, Lena Purdy.

${ }^{139}$ SAQ, File \#2224, Jessie Cameron.

${ }^{140}$ SAQ, File \#2203, Mrs. Robert Wilson.

141 SAQ, File \#2375, John Peacock.

142 SAQ, File \#2211, Mike Bloodoff.

143 James Fletcher, "Farm Weeds of Canada: Introduction," in Farm Weeds in Canada, eds. George H. Clark and James Fletcher (Ottawa, Minister of Agriculture, 1906) 4-16.

144 Fletcher also mentioned how much time and money was lost due to trying to clean the crop seed of weed seed before sending the grain to market, and in trying to eradicate weeds from the fields. It was also interesting to note that having too many weeds in farmer's fields would depreciate the value of the farm. James Fletcher, Farm Weeds of Canada.

145 James Fletcher, Farm Weeds of Canada, 2-3.

${ }^{146}$ A.H. Reginald Buller, in his book Essays on Wheat forewarned homesteaders as to which weeds should be avoided or eliminated. They included Wild Oats, various members of the Mustard family, Field Sowthistle, Canada Thistle, Quack or Couch Grass, Stinkweed and Russian Thistle. (New York: The McMillan Group, 1919).

147 SAQ, File \#2244, N. Scott Branscombe.

148 SAQ, File \#2338, Albert Elderton.

149 SAQ, File \#2214, Kate Stirling.

150 The point of the number of weeds increasing with the number of new homesteaders was substantiated by Clinton Evans who wrote The War on Weeds in the Prairie West in 2002. In his book, he details the weeds which came from Europe, central and eastern Canada, and from the United States. The weed seeds would be mixed in with bags of seed or animal feed, or were in settler effects when the homesteaders travelled to western Canada. (Calgary: University of Calgary Press).

151 SAQ, File \#2208, James Tulloch.

152 SAQ, File \#2216, Amanda Aikenhead.

153 SAQ, File \#2180, Mrs. C.E. Diggle.

154 SAQ, File \#2184, Edith Stilborne

155 Joan Sawka, "There's a World of Good Eating in Horrible Old Weeds." The Edmonton Journal (May 22 , 1971): 24-25.

156 SAQ, File \#2180, Mrs. C.E. Diggle.

${ }^{157}$ Summer-fallowing was a preferred process undertaken by many farmers. It had been widely practiced in Ontario in the 1850s and was relatively successful. As such, it was adopted by those trying to eliminate weeds in the western prairies. See Clinton Evans, The War on Weeds in the Prairie West.

158 SAQ, File \#2203, Robert Wilson.

159 SAQ, File \#2205, Frank Langley.

160 SAQ, File \#2379, Ida Desmoyers.

161 SAQ, File \#2247, Milton Campbell.

162 Another problem experienced by homesteaders and that was harmful to their wheat, oat, barley and rye crops were smut diseases. Smut infiltrates the plant and results in damaged heads and black spores on the leaves which means substantial crop losses. Smut is difficult to eliminate due to the fact that the fungus can be carried by the wind and can be on farm equipment that had previously been used in a smut infested field. Smut can also 
be in grain bags and in the seed that was purchased and was to be planted. See Agriculture Canada, Smut Diseases of Wheat, Barley, Oats and Rye (Ottawa: Minister of Supply and Services, 1984). If the farmer had a suspicion that his purchased seed might be tainted with smut, he would try to treat the seeds before they were planted. As discussed by Ralph Estey, farmers would use salt water or urine on the seeds, however in many cases, these methods proved to be ineffective. See Ralph Estey, Essays on the Early History of Plant Pathology and Mycology in Canada (Montreal: McGill-Queen's University Press, 1994).

${ }^{163}$ SAQ, File \#2184, Edith Stilborne.

${ }^{164}$ SAQ, File \#2181, Frank Kusch.

${ }^{165}$ SAQ, File \#2228, Arthur Tilford.

166 SAQ, File \#2317, Simeon Hiltz.

${ }^{167}$ SAQ, File \#2184, Edith Stilborne.

${ }^{168}$ SAQ, File \#2215, Koozma Tarasoff.

${ }^{169}$ SAQ, File \#2178, Charles Bray.

${ }^{170}$ SAQ, File \#2353, George Hickley.

${ }^{171}$ SAQ, File \#2224, Jessie Cameron.

172 SAQ, File \#2228, Arthur Tilford.

${ }^{173}$ SAQ, File \#2230, James Cooper.

${ }^{174}$ SAQ, File \#2244, N. Scott Branscombe. 